\title{
Effect of Pressor Agents on Blood Pressure, Plasma Renin Activity and Plasma Aldosterone Concentration in Essential Hypertension
}

\author{
Yoshitaka Yамамото, M.D.
}

\section{SUMmary}

The responses of blood pressure, plasma renin activity (PRA) and plasma aldosterone concentration (PAC) to infusion of either angiotensin II $(10 \mathrm{ng} / \mathrm{Kg} / \mathrm{min})$ or norepinephrine $(100 \mathrm{ng} / \mathrm{Kg} / \mathrm{min})$ were observed in 25 patients with essential hypertension. The difference in modes of response between low renin essential hypertension and normal or high renin essential hypertension was analyzed. For comparison, 5 patients with Conn's syndrome, 4 with renovascular hypertension, and 5 normotensive subjects were also studied.

Following infusion of angiotensin II the changes in diastolic blood pressure (DBP) were $+24 \pm 3.0 \mathrm{mmHg}$ in low renin essential hypertension and $+25 \pm 3.1 \mathrm{mmHg}$ in normal or high renin essential hypertension, in PRA $-0.28 \pm 0.06 \mathrm{ng} / \mathrm{ml} / \mathrm{h}$ in low renin essential hypertension and $-0.69 \pm 0.02 \mathrm{mg} / \mathrm{ml} / \mathrm{h}$ in another and in $\mathrm{PAC}+3.7 \pm 1.4$ and $+7.6 \pm 1.8$ $\mathrm{ng} / 100 \mathrm{ml}$ respectively. There was a significant difference in magnitude of response in PRA between the 2 groups of essential hypertension ( $p$ $<0.05$ ).

Norepinephrine induced rise in DBP with decreases both in PRA and PAC. The mean changes in DBP were $+6 \pm 1.4 \mathrm{mmHg}$ in low renin essential hypertension and $+16 \pm 2.2 \mathrm{mmHg}$ in another and the pressor response in the later was significantly greater $(p<0.01)$. The changes in PRA were $-0.14 \pm 0.07 \mathrm{ng} / \mathrm{ml} / \mathrm{h}$ in low renin essential hypertension and $-0.67 \pm 0.26 \mathrm{ng} / \mathrm{ml} / \mathrm{h}$ in normal or high renin essential hypertension, and in PAC $-4.9 \pm 1.3$ and $-3.3 \pm 1.9 \mathrm{ng} / 100 \mathrm{ml}$ respectively. The greater fall in PRA in normal or high renin essential hypertension was observed but the difference between the 2 groups of essential hypertension was not significant. The changes in PAC did not parallel the changes in PRA.

Angiotensin II induced essentially similar effects on blood pressure in both groups but the greater feedback inhibition of PRA was produced by this peptide in normal or high renin essential hypertension than in low renin essential hypertension. Norepinephrine induced significantly greater pressor effect in normal or high renin essential hypertension. The adopted dose of norepinephrine suppressed both PRA and PAC and a

From the Second Department of Internal Medicine (Director: Prof. T. Omae), Faculty of Medicine, Kyushu University, Fukuoka, Japan.

Address for reprint request: Yoshitaka Yamamoto, M.D., First Department of Internal Medicine, Medical College of Miyazaki, 5200, Oaza-Kihara, Kiyotake-cho, Miyazaki-gun, Miyazaki, Japan. Received for publication February 7, 1975. 
tendency to the greater fall in PRA was observed in normal or high renin essential hypertension. There was no difference in responses of PAC to both agents between the 2 groups of essential hypertension.

\section{Additional Indexing Words :}

Angiotension II Norepinephrine

$\mathrm{U}^{\mathrm{N}}$

NTIL the assay method of angiotensin became available it was not possible to accumulate enough information to study human hypertension. However, during the last decade with greater availability of assay methods of the peptides, initial bioassay, ${ }^{1-3)}$ and subsequent radioimmunoassay, ${ }^{4-6)}$ extensive investigations in physiology of renin-angiotensin system have made its role clearer. Moreover, in 1960 it was demonstrated by Genest" and Laragh et $\mathrm{al}^{8 /}$ that angiotensin had direct stimulating effect on aldosterone secretion. Thus, renin-angiotensin-aldosterone (R-A) system is now understood to play an important role in regulation of electrolytes and blood pressure. It has been shown that derangement of this hormonal system is in part involved in the pathogenesis of malignant hypertension ${ }^{10}$ as well as Conn's syndrome. ${ }^{11)}$ However, these represent rather exceptional hypertensive states in which abnormalities of $\mathrm{R}$-A system are more easily demonstrated and altogether these comprise only a small portion of the large hypertensive population. The participation of the R-A system in the pathogenesis and natural history of so-called " essential hypertension" remains unsettled.

Investigation to date, while not generally in agreement, has often reported normal aldosterone secretion in essential hypertension. However, certain abnormal features of aldosterone secretion ${ }^{12}$ and more apparent abnormalities in plasma renin level have been reported. While in the majority of the patients with essential hypertension plasma renin activity (PRA) is normal but in significant numbers it may be either subnormal or abnormally increased. In fact, PRA in approximately $70 \%$ of the patients with uncomplicated essential hypertension does not differ from that in normotensive population. ${ }^{13 / 14)}$ In 20 to $30 \%$ of essential hypertension PRA is lower than normal, ${ }^{15)-18)}$ and it is this group that has attracted the recent research interest in the field of human hypertension.

Although there has been fairly general agreement that responsiveness to vasoactive substances in essential hypertension is increased ${ }^{19)-22}$ ) and that 2 most potent pressor agents, angiotensin II and norepinephrine, have opposite effect on renin release in vivo, ${ }^{23)-26}$ the comparative study of effects of these agents on blood pressure and R-A system between low renin essential hypertension and normal or high renin essential hypertension has not fully accomplished. 
The present study was designed to examine the effects of pressor agents with different modes of action in low renin essential hypertension and normal or high renin essential hypertension. As pressor substances angiotensin II and norepinephrine were employed. The results were also compared to those obtained from the patients with Conn's syndrome, renovascular hypertension and normotensive subjects.

\section{Subjects AND Methods}

Thirty-four hypertensive patients, 22 males and 12 females, were subjected to the present study. Their ages ranged from 18 to 63 , averaging 39.2. In these patients were included 25 patients with essential hypertension (17 males, 8 females), 5 with Conn's syndrome ( 3 males, 2 females), and 4 with renovascular hypertension ( 2 males, 2 females) (Table I). In 20 out of 25 patients with essential hypertension angiotensin infusion test and in 14 norepinephrine infusion test were carried out. Nine of these patients received both angiotensin and norepinephrine infusions. The patients with essential hypertension were divided into 2 groups by the level of ambulation PRA determined prior to infusion test. The lower limit of PRA in normal subjects after 1 hour ambulation being $1.45 \mathrm{ng} / \mathrm{ml} / \mathrm{h}$ in our laboratory, the patients whose ambulation PRA was below this level were classified as low renin essential hypertension (group I) and those with above this level as normal or high renin essential hypertension (group II).

All patients were admitted to the Second Department of Internal Medicine, Kyushu University Hospital and the diagnosis was made on the basis of careful clinical studies. The blood pressure was above $150 \mathrm{mmHg}$ in systole and $90 \mathrm{mmHg}$ in diastole without exception on admission. On all patients with Conn's syndrome and renovascular hypertension were surgical operations performed with success. Five normotensive patients, 3 males and 2 females aged between 26 and 38 averaging 34.0 , were also studied as a control group. They were selected from a group of hospital inpatients and were free from disease of the cardiovascular, renal, or endocrine system and no patient was receiving medication known to affect plasma renin level or electrolyte metabolism such as adrenocortical steroids, diuretics, or sodium containing drugs.

All medication was discontinued and the patients were maintained on a fixed sodium and potassium intake, $170-200 \mathrm{mEq}$ and $50-70 \mathrm{mEq}$ per day respectively, for at least 7 days prior to the study. Twenty-four hour urine specimens were collected for urinary electrolytes and catecholamines in 3 consecutive days and

Table I. Number of Patients Studied

\begin{tabular}{l|r|c|c}
\hline Type of Hypertension & Low Renin & $\begin{array}{c}\text { Normal or } \\
\text { High Renin }\end{array}$ \\
\hline Essential hypertension & 25 & 13 & 12 \\
Conn's syndrome & 5 & 5 & 4 \\
Renovascular hypertension & 4 & & 16 \\
\hline Total & 34 & 18 & \\
\end{tabular}


peripheral venous blood was obtained for determination of blood urea nitrogen (BUN) and serum electrolytes prior to the infusion test.

At the time between 8 and 9 a.m., following 8 hours or more recumbency and overnight fasting $15 \mathrm{ml}$ of venous blood was drawn and another $15 \mathrm{ml}$ after ambulation for 1 hour for determination of control PRA and PAC. Infusion test of angiotensin II or norepinephrine was carried out in the same period after 8 hours' recumbency and fasting. The pressor agents were dissolved in $5 \%$ glucose solution arranging the total infusion volume not to exceed $20 \mathrm{ml}$ and were infused intravenously through antecubital vein with a Sweden constant infusion pump. Angiotensin II supplied as Hypertensin-Ciba, or norepinephrine as dl-noradrenaline was infused for $30 \mathrm{~min}$ at the rate of $10 \mathrm{ng} / \mathrm{Kg} / \mathrm{min}$ and $100 \mathrm{ng} / \mathrm{Kg} / \mathrm{min}$ respectively and these substances were in general well tolerated. The blood pressure measured indirectly by pressure cuff method and pulse rate were determined before infusion and during infusion at 5 min's interval. Collections of venous blood and 2 hours' urine specimens were performed both before and after infusion, and blood samplings were done at the upper extremity opposite to the side of infusion. Electrolytes were measured by flame photometry and urinary catecholamines were determined by modified von Euler's method. ${ }^{27}$ Both PRA and PAC were determined by radioimmunoassay. The determination of PRA was done by a modification of method of Haber and associates ${ }^{4}$ using the kits supplied by CEA-IRE-SORIN, and that of PAC by a modified method of Mayes and associates $\left.{ }^{28}\right)$ using the NIH antialdosterone serum. Normal value of ambulation PRA was 1.45 to $2.60 \mathrm{ng} / \mathrm{ml} / \mathrm{h}$ and that of supine $\mathrm{PAC}$ was 4.4 to $13.5 \mathrm{ng} / 100 \mathrm{ml}$ in our laboratory.

\section{RESULTS}

\section{Clinical data (Table II)}

(1) The patients with essential hypertension received angiotensin II

The age in 11 patients with low ambulation PRA (group I) ranged from 27 to 63 and in 9 with normal or high ambulation PRA (group II) from 18 to 52 years, averaging 45 and 37 respectively. In group II was included 1 patient of age 18 with no known cause for hypertension. Mean DBP determined on 7th to 10th hospital day was 98 in group I and $97 \mathrm{mmHg}$ in group II. In 3 out of 11 in group I and 2 of 9 in group II, DBP was below $90 \mathrm{mmHg}$ on the day of infusion test. Three patients showed Grade I retinopathy and others Grade II in group I. In group II were included 5 patients with Grade I retinopathy and the rest with Grade II. Cardiothoracic ratio (CTR) was above $50 \%$ in 5 patients and in 9 electrocardiographic evidence of left ventricular hypertrophy $(\mathrm{LVH})$ was observed in group I. In group II were included 2 patients with CTR above $50 \%$ and 5 with LVH. Serum sodium values ranged from 141 to $146 \mathrm{mEq} / \mathrm{L}$ in group $I$ and 140 to $144 \mathrm{mEq} / \mathrm{L}$ in group II. Serum potassium values ranged from 3.9 to $4.8 \mathrm{mEq} / \mathrm{L}$ in group I and 3.8 to $4.6 \mathrm{mEq} / \mathrm{L}$ in group II, averaging 4.3 and $4.1 \mathrm{mEq} / \mathrm{L}$ respectively. Urinary catecholamines, 17-KS and 17-OHCS were within normal limits scat- 
Table II. Clinical Data of Patients with Essential Hypertension for the Study of Angiotension II and Norepinephrine Infusion

\begin{tabular}{|c|c|c|}
\hline Angiotension II inf. & $\begin{array}{c}\text { Group } I \\
(\mathrm{n}=11)\end{array}$ & $\begin{array}{c}\text { Group II } \\
(n=9)\end{array}$ \\
\hline Age & $45 \pm 2.8$ & $37 \pm 4.2$ \\
\hline GTR $(\%)$ & $51 \pm 2.2$ & $47 \pm 2.3$ \\
\hline \multicolumn{3}{|l|}{ Serum } \\
\hline $\mathrm{Na}(\mathrm{mEq} / \mathrm{L})$ & $143 \pm 0.6$ & $142 \pm 1.0$ \\
\hline $\mathrm{K}(\mathrm{mEq} / \mathrm{L})$ & $4.3 \pm 0.1$ & $4.1 \pm 0.1$ \\
\hline \multicolumn{3}{|l|}{ Urine } \\
\hline $\mathrm{Na}(\mathrm{mEq} / 24 \mathrm{~h})$ & $128 \pm 11$ & $114 \pm 7$ \\
\hline $\mathrm{K}(\mathrm{mEq} / 24 \mathrm{~h})$ & $28 \pm 3.4$ & $26 \pm 4.1$ \\
\hline $17-\mathrm{KS}(\mathrm{mg} / 24 \mathrm{~h})$ & $5.0 \pm 0.8$ & $6.3 \pm 0.8$ \\
\hline 17-OHCS $(\mathrm{mg} / 24 \mathrm{~h})$ & $4.5 \pm 0.4$ & $6.6 \pm 1.2$ \\
\hline NE $(\mu \mathrm{g} / 24 \mathrm{~h})$ & $23 \pm 2.8$ & $22 \pm 7.6$ \\
\hline $\mathrm{DBP}(\mathrm{mmHg})$ & $98 \pm 5.4$ & $97 \pm 5.4$ \\
\hline \multicolumn{3}{|l|}{ PRA (ng/ml/h) } \\
\hline supine & $0.4 \pm 0.1$ & $1.5 \pm 0.2$ \\
\hline ambulation & $0.8 \pm 0.1$ & $2.6 \pm 2.7$ \\
\hline \multicolumn{3}{|l|}{$\mathrm{PAC}(\mathrm{ng} / 100 \mathrm{ml})$} \\
\hline supine & $7.4 \pm 2.6$ & $10.7 \pm 2.7$ \\
\hline Norepinephrine inf. & $(n=6)$ & $(n=8)$ \\
\hline Age & $47 \pm 4.7$ & $33 \pm 4.6$ \\
\hline CTR (\%) & $50 \pm 1.3$ & $46 \pm 0.8$ \\
\hline \multicolumn{3}{|l|}{ Serum } \\
\hline $\mathrm{Na}(\mathrm{mEq} / \mathrm{L})$ & $142 \pm 0.7$ & $143 \pm 0.5$ \\
\hline $\mathrm{K}(\mathrm{mEq} / \mathrm{L})$ & $4.3 \pm 0.2$ & $4.0 \pm 0.2$ \\
\hline \multicolumn{3}{|l|}{ Urine } \\
\hline $\mathrm{Na}(\mathrm{mEq} / 24 \mathrm{~h})$ & $108 \pm 6$ & $122 \pm 1.6$ \\
\hline $\mathrm{K}(\mathrm{mEq} / 24 \mathrm{~h})$ & $32 \pm 5.9$ & $27 \pm 3.8$ \\
\hline $17-\mathrm{KS}(\mathrm{mg} / 24 \mathrm{~h})$ & $5.7 \pm 0.9$ & $7.5 \pm 0.8$ \\
\hline $17-\mathrm{OHCS}(\mathrm{mg} / 24 \mathrm{~h})$ & $9.8 \pm 1.1$ & $7.2 \pm 1.0$ \\
\hline $\mathrm{NE}(\mu \mathrm{g} / 24)$ & $21 \pm 5.9$ & $24 \pm 7.4$ \\
\hline $\mathrm{DBP}(\mathrm{mmHg})$ & $98 \pm 5.9$ & $92 \pm 4.5$ \\
\hline \multicolumn{3}{|l|}{ PRA (ng/ml/h) } \\
\hline supine & $0.3 \pm 0.1$ & $1.3 \pm 0.3$ \\
\hline ambulation & $0.8 \pm 0.1$ & $3.0 \pm 0.5$ \\
\hline \multicolumn{3}{|l|}{$\operatorname{PAC}(\mathrm{ng} / 100 \mathrm{ml})$} \\
\hline supine & $10 \pm 2.7$ & $8.5 \pm 3.0$ \\
\hline
\end{tabular}

The values represent mean \pm S.E.

Group I: Subjects with low PRA. Group II : Subjects with normal or high PRA.

Abbreviations : $\mathrm{CTR}=$ cardiothoracic ratio, $\mathrm{NE}=$ norepinephrine, $\mathrm{DBP}=$ diastolic blood pressure, $\mathrm{PRA}=$ plasma renin activity, $\mathrm{PAC}=$ plasma aldosterone concentration. 
tering in a small range. Supine PRA was low in 7 patients and normal in 4 and ambulation PRA was below normal in all the patients in group I. In group II supine PRA was slightly below normal in 1 patient, normal in 7, and high in 1 and ambulation PRA was normal in 4 and high in 5 . Supine PAC varied in group I showing 6 patients with low PAC, 3 with normal, and 2 with high PAC. There were 1 patient with low PAC, 5 with normal, and 3 with low PAC in group II.

(2) The patients with essential hypertension received norepinephrine

The age ranged from 34 to 63 in 6 patients in group I and from 18 to 58 in 8 patients in group II, averaging 47 and 33 years respectively. Mean DBP was 98 in group I and $92 \mathrm{mmHg}$ in group II. In 1 patient in group I and 2 in group II, DBP was below $90 \mathrm{mmHg}$ on the day of infusion test. All patients showed Grade II retinopathy in group I and in group II were included 4 patients with Grade I and 4 with Grade II retinopathy. CTR was above $50 \%$ in 3 patients and LVH was evident in 4 in group I. No patient showed CTR above $50 \%$ and in 6 patients $\mathrm{LVH}$ was found in group II. Supine PRA was low in 3 patients and normal in another 3 and ambulation PRA was below normal without exception in group I. In group II were included 2 patients with low, 6 with normal, and 1 with high supine PRA. Ambulation PRA was normal in 3 patient and high in 5 in group II. Supine PAC was within normal limits in all the patients in group I, while that in group II was low in 2, normal in 5, and high in 1 patient. Serum sodium values ranged from 141 to $145 \mathrm{mEq} / \mathrm{L}$ in group $I$ and from 141 to $146 \mathrm{mEq} / \mathrm{L}$ in group II, averaging 142 and $143 \mathrm{mEq} / \mathrm{L}$ respectively. Serum potassium values were between 3.7 and $4.8 \mathrm{mEq} / \mathrm{L}$, averaging 4.3 in group I and between 3.5 and $4.5 \mathrm{mEq} / \mathrm{L}$, averaging 4.0 in group II. Urinary catecholamines, $17-\mathrm{KS}$ and $17-\mathrm{OHCS}$ were within normal limits in a small range both in group I and group II.

Although mean age and CTR appeared somewhat higher in the group of low renin essential hypertension than in that of normal or high renin essential hypertension, there was no significant difference of control values between the 2 groups of essential hypertension.

2. Infusion test

(1) Effect of angiotensin II

In 5 of normotensive subjects infusion of angiotensin II was associated with rise in DBP, $+19 \pm 2.3 \mathrm{mmHg}$ (mean \pm S.E.), and decrease in PRA, $-0.3 \pm 0.1 \mathrm{ng} / \mathrm{ml} / \mathrm{h}$. Though determination of $\mathrm{PAC}$ in the normotensives was done only in 1 subject, the change in PAC was $+4.7 \mathrm{ng} / 100 \mathrm{ml}$ in this case with antiotensin II (Table III). 
Table III. Effect of Angiotensin II or Norepinephrine Infusion in Normotensive Subjects

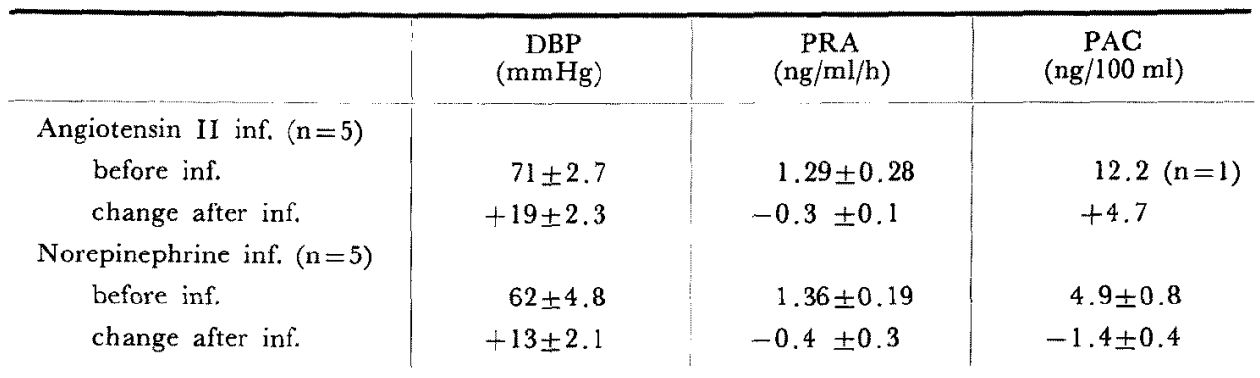

The values represent mean \pm S.E.

Abbreviations: $\mathrm{DBP}=$ diastolic blood pressure, $\mathrm{PRA}=$ plasma renin activity, $\mathrm{PAC}=$ plasma aldosterone concentration.

Table IV. Effect of Angiotensin II or Norepinephrine Infusion in Conn's Syndrome

\begin{tabular}{c|c|c|c}
\hline & $\begin{array}{c}\text { DBP } \\
(\mathrm{mmHg})\end{array}$ & $\begin{array}{c}\text { PRA } \\
(\mathrm{ng} / \mathrm{ml} / \mathrm{h})\end{array}$ & $\begin{array}{c}\text { PAC } \\
(\mathrm{ng} / 100 \mathrm{ml})\end{array}$ \\
\hline $\begin{array}{c}\text { Angiotensin II inf. }(\mathrm{n}=5) \\
\text { before inf. }\end{array}$ & $111 \pm 6.3$ & & $0.13 \pm 0.03$ \\
$\begin{array}{c}\text { change after inf. } \\
\text { Norepinephrine inf. }(\mathrm{n}=2)\end{array}$ & $+29 \pm 6.2$ & $+0.09 \pm 0.08$ & $+6.7 \pm 0.8$ \\
$\begin{array}{l}\text { before inf. } \\
\text { change after inf. }\end{array}$ & 116,96 & $0,0.17$ & 24,13 \\
& $+5,+8$ & $\pm 0, \pm 0.10$ & $+1.2,+2.2$
\end{tabular}

The values in angiotensin II infusion represent mean \pm S.E. and those in norepinephrine infusion represent for individuals.

Abbreviations: $\mathrm{DBP}=$ diastolic blood pressure, $\mathrm{PRA}=$ plasma renin activity, $\mathrm{PAC}=$ plasma aldosterone concentration.

In 5 patients with Conn's syndrome, whose control PRA was low, marked pressor effect, $+29 \pm 6.2 \mathrm{mmHg}$, was observed with angiotensin II and this was associated with no remarkable change in PRA, $+0.09 \pm 0.08 \mathrm{ng} / \mathrm{ml} / \mathrm{h}$, but significant rise in $\mathrm{PAC},+6.7 \pm 0.8 \mathrm{ng} / 100 \mathrm{ml}$, (Table IV).

In 4 patients with renovascular hypertension with abnormally high control PRA, the change in DBP was $+18 \pm 1.7 \mathrm{mmHg}$, in PRA $-2.5 \pm 0.5$ $\mathrm{ng} / \mathrm{ml} / \mathrm{h}$, and $\mathrm{PAC}+7.6 \pm 1.9 \mathrm{ng} / 100 \mathrm{ml}$ following angiotensin II infusion (Table V).

In group $I$ and group II of essential hypertension, the changes in DBP were $+25 \pm 3.0$ and $+24 \pm 3.1 \mathrm{mmHg}$, the changes in PRA $-0.28 \pm 0.06$ and $-0.69 \pm 0.20 \mathrm{ng} / \mathrm{ml} / \mathrm{h}$, and in PAC $+3.7 \pm 1.4$ and $+7.6 \pm 1.8 \mathrm{ng} / 100 \mathrm{ml} \mathrm{re}-$ spectively. There was a greater response of PRA in group II than in group $I \quad(p<0.05)$ but no significant difference in magnitude of changes in DBP 
Table V. Effect of Angiotensin II or Norepinephrine Infusion in Renovascular Hypertension

\begin{tabular}{c|c|c|c}
\hline & $\begin{array}{c}\text { DBP } \\
(\mathrm{mmHg})\end{array}$ & $\begin{array}{c}\text { PRA } \\
(\mathrm{ng} / \mathrm{ml} / \mathrm{h})\end{array}$ & $\begin{array}{c}\text { PAC } \\
(\mathrm{ng} / \mathrm{l00} \mathrm{ml})\end{array}$ \\
\hline $\begin{array}{c}\text { Angiotensin II inf. }(\mathrm{n=4}) \\
\text { before inf. }\end{array}$ & $114 \pm 4.2$ & $3.67 \pm 0.46$ & $17 \pm 6.0$ \\
$\begin{array}{c}\text { change after inf. } \\
\text { Norepinephrine inf. }(\mathrm{n}=2)\end{array}$ & $+18 \pm 1.7$ & $-2.5 \pm 0.50$ & $+7.6 \pm 1.9$ \\
$\begin{array}{l}\text { before inf. } \\
\text { change after inf. }\end{array}$ & 118,97 & $4.06,4.00$ & 8,10 \\
\end{tabular}

The values in angiotensin II infusion represent mean \pm S.E. and those in norepinephrine infusion represent for individuals.

Abbreviations: $\mathrm{DBP}=$ diastolic blood pressure, $\mathrm{PRA}=$ plasma renin activity, $\mathrm{PAC}=$ plasma aldosterone concentration.

Table VI. Effect of Angiotensin II or Norepinephrine Infusion in Essential Hypertension

\begin{tabular}{|c|c|c|}
\hline Angiotensin II Inf. & $\begin{array}{c}\text { Group I } \\
(\mathrm{n}=11)\end{array}$ & $\underset{(n=9)}{\text { Group II }}$ \\
\hline $\begin{array}{l}\Delta \mathrm{DBP}(\mathrm{mmHg}) \\
\Delta \mathrm{PRA}(\mathrm{ng} / \mathrm{ml} / \mathrm{h}) \\
\Delta \mathrm{PAC}(\mathrm{ng} / 100 \mathrm{ml}) \\
\Delta \mathrm{SNa}(\mathrm{mEq} / \mathrm{L}) \\
\Delta \mathrm{SK}(\mathrm{mEq} / \mathrm{L}) \\
\Delta \mathrm{UNa}(\mathrm{mEq} / \mathrm{h}) \\
\Delta \mathrm{UK}(\mathrm{mEq} / \mathrm{h}) \\
\Delta \mathrm{UVol}(\mathrm{ml} / \mathrm{h})\end{array}$ & $\begin{array}{l}+25 \pm 3.0 \\
-0.28 \pm 0.06 \\
+3.7 \pm 1.4 \\
-0.13 \pm 0.32 \\
+0.08 \pm 0.08 \\
-1.5 \pm 0.7 \\
-1.0 \pm 0.5 \\
-6.6 \pm 11.2\end{array}$ & $\begin{array}{l}+24 \pm 3.1 \\
-0.69 \pm 0.20^{*} \\
+7.6 \pm 1.8 \\
+0.33 \pm 0.56 \\
+0.02 \pm 0.17 \\
-3.8 \pm 2.0 \\
+0.2 \pm 0.4 \\
-2.1 \pm 10.1\end{array}$ \\
\hline Norepinephrine Inf. & $(n=6)$ & $(n=8)$ \\
\hline $\begin{array}{l}\Delta \mathrm{DBP}(\mathrm{mmHg}) \\
\Delta \mathrm{PRA}(\mathrm{ng} / \mathrm{ml} / \mathrm{h}) \\
\Delta \mathrm{PAC}(\mathrm{ng} / 100 \mathrm{ml}) \\
\Delta \mathrm{SNa}(\mathrm{mEq} / \mathrm{L}) \\
\Delta \mathrm{SK}(\mathrm{mEq} / \mathrm{L}) \\
\Delta \mathrm{UNa}(\mathrm{mEq} / \mathrm{h}) \\
\Delta \mathrm{UK}(\mathrm{mEq} / \mathrm{h}) \\
\Delta \mathrm{UVol}(\mathrm{ml} / \mathrm{h})\end{array}$ & $\begin{array}{l}+6 \pm 1.4 \\
-0.14 \pm 0.07 \\
-4.9 \pm 1.3 \\
+0.17 \pm 0.48 \\
+0.13 \pm 0.08 \\
+0.9 \pm 2.2 \\
+0.9 \pm 0.5 \\
+2.4 \pm 3.5\end{array}$ & $\begin{aligned} &+16 \pm 2.2^{* *} \\
&-0.67 \pm 0.26 \\
&-3.3 \pm 2.0 \\
& 0 \pm 0.24 \\
&+0.08 \pm 0.14 \\
&+4.7 \pm 3.6 \\
&+1.2 \pm 1.6 \\
&+16 \pm 13.3\end{aligned}$ \\
\hline
\end{tabular}

The values represent mean \pm S.E.

* $\mathrm{p}<0.05$, ** $\mathrm{p}<0.01$.

Abbreviations: $\Delta=$ change after infusion, $D B P=$ diastolic blood pressure, $P R A=$ plasma renin activity, $\mathrm{PAC}=$ plasma aldostcrone concentration, $\mathrm{SNa}=$ serum sodium, $\mathrm{SK}=$ serum potassium, $\mathrm{UNa}=$ urinary sodium, $\mathrm{UK}=$ urinary potassium, $\mathrm{UVol}=$ urine volume. 
and PAC existed between the 2 groups of essential hypertension. The changes in serum and urinary sodium and potassium were not remarkable and the effect of angiotensin II on urine volume was variable (Table VI).

When the responses were compared between the normotensive subjects and the patients in group I and group II no significant difference was observed.

(2) Effect of norepinephrine

Norepinephrine induced rise in DBP, $+13 \pm 2.1 \mathrm{mmHg}$, falls in PRA and $\mathrm{PAC},-0.4 \pm 0.3 \mathrm{ng} / \mathrm{ml} / \mathrm{h}$ and $-1.4 \pm 0.4 \mathrm{ng} / 100 \mathrm{ml}$ respectively in 5 normotensive subjects (Table III).

Infusion of norepinephrine for $30 \mathrm{~min}$ at the rate of $100 \mathrm{ng} / \mathrm{Kg} / \mathrm{min}$ produced changes in DBP +5 and $+8 \mathrm{mmHg}$, in PRA \pm 0 and $+0.10 \mathrm{ng} / \mathrm{ml} / \mathrm{h}$, and in $\mathrm{PAC}+1.2$ and $+2.2 \mathrm{ng} / 100 \mathrm{ml}$ in 2 patients with Conn's syndrome (Table IV).

In 2 patients with renovascular hypertension the changes in DBP were +4 and $+4 \mathrm{mmHg}$, in PRA -1.70 and $-3.30 \mathrm{ng} / \mathrm{ml} / \mathrm{h}$, and in PAC -5.7 and $-8.1 \mathrm{ng} / 100 \mathrm{ml}$ following infusion of norepinephrine (Table V).

Pressor effects were thus minimum in patients with Conn's syndrome and renovascular hypertension.

In group I and group II of essential hypertension, mean changes in DBP were $+6 \pm 1.4$ and $+16 \pm 2.2 \mathrm{mmHg}$, the changes in PRA $-0.14 \pm 0.07$ and $-0.67 \pm 0.26 \mathrm{ng} / \mathrm{ml} / \mathrm{h}$, and in $P A C-4.9 \pm 1.3$ and $-3.3 \pm 2.0 \mathrm{ng} / 100 \mathrm{ml}$ respectively (Table VI). The change in DBP was significantly greater in group II than in group I of essential hypertension following infusion of norepinephrine $(p<0.01)$. Though somewhat greater fall in average PRA in group II was observed, the difference was not significant statistically. No remarkable change in serum and urinary sodium and potassium was observed and urine volume was variable with norepinephrine.

There was a significant difference in pressor effect between the normotensive subjects and the patients in group I essential hypertension $(p<0.01)$.

\section{Discussion}

Though the definition of low renin essential hypertension is not strictly established, the term is frequently used for the patient with low PRA not responding to stimuli for renin release such as sodium depletion or upright posture. ${ }^{29)-32)}$ Since the function of R-A system is closely related to electrolyte metabolism, determination of renin and aldosterone should be done under the rigid dietary control of salt balance. In the present study, therefore, the determination was performed after the patient had been put on the diet con- 
taining a fixed amount of sodium and potassium for at least 7 days to make urinary sodium and potassium excretion stable. The grouping of the patients of essential hypertension presented here was made by the PRA after ambulation for 1 hour, and this was based on our experience that Conn's syndrome could be distinguished in this way from other low renin hypertension with roughly $70 \%$ accuracy when the aged paitents of 70 years and over were excluded. For more strict separation of low renin hypertension, further stimulation of renin release with administration of furosemide was adopted.

The measurement of PRA was done by a modified method of Haber and associates, ${ }^{4}$ ' which is the radioimmunoassay of angiotensin I generated during 3 hours' incubation under the condition of preventing a degradation of this peptide and of maximizing the action of renin at $\mathrm{pH} 5.5$ to 6.0 . With this method angiotensin I could be determined with a good precision in the range 0.05 to $0.40 \mathrm{ng} / \mathrm{ml}$. In our laboratory the least detectable level is $0.07 \pm$ $0.01 \mathrm{ng} / \mathrm{ml} / \mathrm{h}$ with the reproducibility of $\pm 11.6 \%$ (S.D.). Sampling was performed under close observation of the subjects and blood was collected in the prechilled siliconized glass tube containing appropriate amount of ethylenediaminetetraacetic acid (EDTA) $(1 \mathrm{mg} / \mathrm{ml}$ of blood). The procedure, therefore, was considered suitable to perform the analytical study.

Though pressor response to angiotensin II in patients with Conn's syndrome was significantly greater than that in those with renovascular hypertension in the present study $(p<0.02)$, there was no significant difference in pressor response to angiotensin II between low renin essential hypertension and normal or high renin essential hypertension. In essential hypertension, pressor response to angiotensin II seemed not to reflect endogenous renin level in blood. Kaplan and Silah ${ }^{33}$ ) suggested that renovascular hypertension could be differentiated from essential hypertension with its smaller pressor response to angiotensin II. However, in several studies, ${ }^{34), 35)}$ no significant difference of pressor effect to this substance could be found between the patients with renovascular hypertension and essential hypertension, suggesting that the pressor response to angiotensin II did not always reflect the circulating angiotensin II level. Even in Conn's syndrome, Weidman ${ }^{36)}$ reported normal pressor response to angiotensin II.

As shown in Tables IV and V, the response of blood pressure to norepinephrine in 2 patients with Conn's syndrome and 2 with renovascular hypertension was minimum. Mendlowitz ${ }^{20)}$ and Distler ${ }^{37)}$ reported similar results in renovascular hypertension. More complicated factors might be involved in pressor response to vasoactive substance in these secondary hypertension. Significantly greater response of blood pressure to norepinephrine infusion was apparent in normal or high renin essential hypertension than in 
low renin essential hypertension. Increased pressor response to norepinephrine in essential hypertension was demonstrated by many workers, ${ }^{38)}{ }^{40)}$ but the comparison was done only between the patients with essential hypertension and normotensive subjects. In the present study, norepinephrine produced a smaller rise in blood pressure in patients with low renin essential hypertension than in normotensive patients $(p<0.01)$ but there was no difference of change in blood pressure between the patients with normal or high renin essential hypertension and the normotensives.

Though the response to vasoactive agent is an integrated function of many factors, there is a possibility that metabolic alteration may in part be responsible for the phenomenon of increased responsiveness in essential hypertension. In regard to catecholamine metabolism, the substance which is released primarily by sympathetic nerve is norepinephrine and when it is infused much is stored in tissues. When norepinephrine stores are depleted in tissues by reserpine, guanethidine, or $\alpha$-methyldopa, the response to infused norepinephrine is increased. ${ }^{41,42)}$ In addition, angiotensin II is known to liberate norepinephrine from stores in sympathetic nerve endings in various tissues. ${ }^{43,44)}$ In this respect, in normal or high renin essential hypertension the relatively higher circulating angiotensin may possibly be related to depleting stored norepinephrine to higher degree and this may be reflected by the greater rcsponsiveness to norepinephrine in this group of essential hypertension. On the other hand, however, Distler ${ }^{37)}$ demonstrated that higher doses of tyramine were required to induce pressor effect in the patients with low plasma renin concentration.

It has also been shown that angiotensin tachyphylaxis was abolished by norepinephrine, ${ }^{45}$ and here may be another possibility in modifying responsiveness in essential hypertension with different levels of endogenous angiotensin.

With these possibilities, interaction of R-A and sympathetic nervous system seems to play some important role in regulating blood pressure, though it still requires more study.

Raising blood pressure, angiotensin II uniformly produced decrease in PRA and increase in PAC as already seen in several previous reports. ${ }^{46,47)}$ There was a significant difference in magnitude of change in PRA between low renin essential hypertension and normal or high renin essential hypertension. Those with normal or high renin essential hypertension exhibited the greater decrease in PRA following angiotensin II infusion. PRA can be influenced by change in blood pressure per se baroreceptor function but this seems to play a relatively minor role in this situation. Though blood pressure itself is a potent regulator of renin release, a different response of PRA to 
angiotensin II between low renin essential hypertension and normal or high renin essential hypertension is not likely to be produced only by similar change in blood pressure. In general, suppression of PRA induced by angiotensin II can be explained by negative feedback mechanism on renin release, ${ }^{48,49)}$ but the phenomenon of different change in PRA between the 2 groups of essential hypertension still remained unsettled.

Potassium balance can possibly influence renin release with its direct action on the kidney, ${ }^{50)}$ but no positive evidence of disorder of electrolyte balance was demonstrated in the result presented here. Therefore, it might be possible to postulate that feedback inhibition of renin release could be augmented when the circulating angiotensin II level is high.

The concept of direct stimulating action of angiotensin II on adrenal cortex may be supported by the data presented here showing the rise in PAC with angiotensin II infusion. Amplifications of PAC were similar in both groups of essential hypertension. In patients with Conn's syndrome, control PAC was high but the magnitude of change in PAC did not differ from those with lower control PAC (Table III). Thus, responsiveness of PAC seemed not to reflect the circulating angiotensin II level.

In sheep studies of sodium depletion, aldosterone secretion was not precisely dependent on proportional rise of blood angiotensin II and there was also a dissociation between aldosterone secretion rate and blood angiotensin II during rapid correction of sodium deficiency. ${ }^{51-54)}$ It seems to be that the adrenocortical response to additional angiotensin II is blunted when the basal level of the peptide is already high, in which situation adrenocortical secretory mechanism is stimulated nearly to maximum level. In fact, in patients with cirrhosis of the liver whose endogenous angiotensin level is high exogenous angiotensin II infusion exerted little or no additive effect on aldosterone secretion. ${ }^{16)}$ Besides, Laragh and associated ${ }^{16)}$ demonstrated that the patients with low renin essential hypertension were heterogenous as far as aldosterone was concerned. Low renin essential hypertension exhibited a variety of R-A patterns and further included low fixcd plasma renin level in association with a normal or high aldosterone secretion to stimuli. This may also explain this renin-aldosterone dissociation. On the other hand, Gagnon ${ }^{54}$ ) described that long time suppression of PRA was associated with a decrease in reactivity of aldosterone to the stimulation of angiotensin II but the results shown here were not compatible. Potassium loss is accounted for inhibition of aldosterone secretion ${ }^{16)}$ and the degree of aldosterone stimulation by potassium is of as same order of magnitude as that produced by angiotensin II, ${ }^{16}$ ) but no positive evidence of electrolyte disturbance was demonstrated in the present study. 
Infusion of norepinephrine reduced both PRA and PAC and the reduction in PRA tended to be greater in normal or high renin essential hypertension but the difference between the 2 groups was not significant, while PAC was reduced in similar degree in the both groups of essential hypertension. Evidences have been shown by many workers that infusion of norepinephrine was accompanied by distinct increase in both renin release and aldosterone secretion. 37),45),55)-57) Adrenergic activity has been considered to be one of the major factors regulating renin release and there were reports indicating a direct effect of catecholamines on adrenergic receptor related to renin producing JG cells. ${ }^{24)}$ This view was also supported by studies in the nonfiltering kidney preparation where the renin stimulating effect of norepinephrine persisted after papaverine treatment to prevent a fall in renal blood flow. ${ }^{58}$ ) Furthermore, the recent work suggests that renin secretion provoked by catecholamine infusion or direct sympathetic stimulation is mediated by $\beta$ receptor. ${ }^{59)-62)}$ Thus the direct effect of adrenergic hormones on renin secretion seems likely. In those studies, however, norepinephrine was administered either directly into the renal artery or in larger doses intravenously. Ueda and colleagues ${ }^{57)}$ demonstrated that systemic infusion of norepinephrine with doses below $10 \mu \mathrm{g} / \mathrm{Kg} / \mathrm{min}$ produced no significant change in renal vein renin activity and at the same time this was associated with slight increase in renal blood flow.

In the present study norepienphrine was infused intravenously for 30 min at the rate of $0.1 \mu \mathrm{g} / \mathrm{Kg} / \mathrm{min}$ and this produced moderate rise in DBP with decreases in PRA. It seems to be possible that when this substance is given systemically in small doses, significant amount to stimulate JG cells could not reach the renal circulation and the renin release be suppressed through change in renal circulation under the influence of norepinephrine induced systemic pressor effect. This view could be supported by the results presented here that significantly greater pressor response was associated with larger fall of PRA, though not significant, in normal or high renin essential hypertension. While catecholamines may have significant effect on aldosterone secretion, the effect is not consistent. ${ }^{81,46), 61)}$ Norepinephrine at times can suppress the increased aldosterone secretion rate, this would happen with sodium depletion. The factors known to influence the adrenal aldosterone secretion are renin-angiotensin system, $\mathrm{ACTH}$, serum $\mathrm{Na}$ and $\mathrm{K}$, and possible fifth factor. ${ }^{63)}$ In the present study, however, electrolyte balance was strictly controlled. ACTH may also participate particularly in this acute situation but it stimulates aldosterone secretion. It has been suggested that the influence of catecholamines is indirect ${ }^{8)}$ and the observed change could thus be consequent either to decreased PRA or to blood pressure elevation. 
If a larger dose of norepinephrine is employed the effect on renal renin release and adrenocortical aldosterone secretion would be different and the different effects on PRA and PAG might be observed.

\section{ConGLUSIONS}

To obtain more information about low renin or suppressed renin essential hypertension comparative study was performed of the effects of pressor agents, angiotensin II or norepinephrine, on blood pressure, plasma renin activity and plasma aldosterone concentration between low renin essential hypertension and normal or high renin essential hypertension. Some hypertensive patients with known etiologies were also studied for comparative analysis. The results obtained from the present study were as follows;

1) There was no difference of blood pressure elevation responding to angiotensin II between low renin essential hypertension and normal or high renin essential hypertension.

2) The significantly greater feedback inhibition of plasma renin activity was induced by angiotensin II in normal or high renin essential hypertension than in low renin essential hypertension.

3) Intravenous infusion of norepinephrine at the rate of $100 \mathrm{ng} / \mathrm{Kg} / \mathrm{min}$ suppressed both plasma renin activity and plasma aldosterone concentration.

4) Norepinephrine induced significantly greater pressor effect in normal or high renin essential hypertension and this was accompanied by somewhat greater fall in plasma renin activity.

5) Angiotensin II produced increase in plasma aldosterone concentration and infusion of norepinephrine at the rate of $100 \mathrm{ng} / \mathrm{Kg} / \mathrm{min}$ decreased it. There was no difference of mode of responses to both agents between low renin essential hypertension and normal or high renin essential hypertension.

6) In low renin essential hypertension plasma renin activity was little influenced by both angiotensin II and norepinephrine. Despite the poor response of plasma renin activity the response of plasma aldosterone concentration to infusions of both agents varied in low renin essential hypertension.

\section{ACKNOWLEDGEMENTS}

The author wishes to express his gratitude to Professor Dr. Teruo Omae for his kind supervision and useful criticism, Associate Professor Dr. Kenjiro Tanaka for his supervision and advice and the staffs of the 17th Labo. of Second Dept. of Internal Medicine, Fuculty of Medicine, Kyushu University for cooperations. He also deeply appreciates the technical support of Mrs. Sumiko Nakamuta. The author is also indebted to the National Institute of Health, U.S.A., who kindly gave antialdosterone serum. 


\section{REFERENCES}

1. Helmer OM, Judson WE: The quantitative determination of renin in the plasma of patients with arterial hypertension. Circulation 27: 1050, 1963

2. Boucher R, Veyrat R, DeChamplain J, Genest J: New procedure for measurement of human plasma angiotensin and renin activity levels. Canad med Ass J 99: 104, 1960

3. Pickens PT, Bumpus FM, Lloyd AM, Smeby RR, Page IH: Measurement of renin activity in human plasma. Circulat Res 17: 438, 1965

4. Haber E, Koener T, Page LB, Purnode A: Application of radioimmunoassay of angiotensin I to the physiologic measurements of plasma renin activity in normal human subject. J Clin Endocrinol 29: 1349, 1969

5. Cohen E, Grim CE, Conn JM, Blough WM, Guyer RB, Lucas CP: Accurate and rapid measurement of plasma renin activity by radioimmunoassay. J Lab Clin Med 77: 1025, 1971

6. Fukuchi $S$, Takeuchi $\mathbf{T}$, Torikai $\mathbf{T}$ : Determination of plasma renin activity by radioimmunoassay of angiotensin I. Clin Sci 44: 43, 1973

7. Genest J: Adrenocortical function in essential hypertension: An International Symposium. Berlin, Springer-Verlag, p 126, 1960

8. Laragh JH, Angers M, Kelley WG, Lieberman S: Hypotensive agents and pressor substances: The effect of epinephrine, norepinephrine, angiotensin II and others on the secretory rate of aldosterone in man. J Am med Ass 174: 234, 1960

9. Laragh JH, Ulick S, Januszewicz W, Deming WB, Kelly WG, Lieberman S: Aldosterone secretion and primary and malignant hypertension. J Clin Invest 39: 1091, 1960

10. Eide I: Renovascular hypertension in rats immunized with angiotension II. Circulat Res 30: 149,1972

11. Conn JW: Plasma renin activity in primary aldosteronism. Importance in differential diagnosis and in research of essential hypertension. J Am med Ass 190: 134, 1964

12. Leidingham JGG, Bull MB, Laragh JH: The meaning of aldosterone in hypertensive disease. Circulat Res 20-21 (suppl II): 177, 1967

13. Brunner HR, Laragh JH, Baer L, Newton MA, Goodwin FT, Krakoff LR, Bard RH, Buhler FR: Essential hypertension: renin and aldosterone, heart attack and stroke. New Engl J Med 286: 441, 1972

14. Gunnels J, Grim CE, Robinson RR, Wildermann NM: Plasma renin activity in healthy subjects and patients with hypertension. Preliminary experience with a rapid and quantitative bioassay. Arch intern Med 119: 232, 1967

15. Helmer OM, Judson WE: Metabolic studies on hypertensive patients with suppressed plasma renin activity not due to hyperaldosteronism. Circulation 38: 965, 1968

16. Laragh JH, Sealey J, Brunner HR: The control of aldosterone secretion in normal and hypertensive man. Abnormal renin-aldosterone patterns in low renin hypertension. Am J Med 53: 649, 1972

17. Jose A, Crout J, Kaplan NM: Suppressed plasma renin activity in essential hypertension, roles of plasma volume, blood pressure and sympathetic nervous system. Ann intern Med 72: 9,1970

18. Channick BJ, Adlin EV, Marks AD: Suppressed plasma renin activity in hypertension. Arch intern Med (Chicago) 123: 131, 1969

19. Greisman SE: The reaction of the capillary bed of the nailfold to the continuous intravenous infusion of levonorepinephrine in patients with normal blood pressure and with essential hypertension. J Clin Invest 33: 975, 1954

20. Mendlowitz M, Naftchi NE, Gitlow SE, Wolf RE: Vascular responsiveness in hypertensive and hypotensive states. Geriatrics 20:797, 1965

21. Kaplan NM, Silah JG: The effect of angiotension II on blood pressure in humans with hypertensive disease. J Clin Invest 43: 656, 1964 
22. Gaskel P: Digital vascular response to angiotension II in normotensive and hypertensive subjects. Circulat Res 20: 174, 1967

23. Vander AJ: Effect of catecholamines and renal nerves on renin secretion in anesthetized dogs. Am J Physiol 209: 659, 1965

24. Michelakis AM, Caudle $\mathrm{J}$ : In vitro stimulation of renin production by epinephrine, norepinephrine and cyclic AMP. Proc Soc Exp Biol Med (NY) 130: 748, 1969

25. Genest J, DeChmplain J, Veyrat R, Boucher R, Tremblay GY, Strong CG, Koiw E, MarcAurele $\mathrm{J}$ : Role of the renin-angiotensin system in various physiological and pathological states. Hypertension (Am Heart Ass Monogr) 13: 97, 1965

26. Blair-West RD, Coghlan JP, Denton DA, Funder JW, Scoggins BA, Wright RD: Inhibition of renin secretion by systemic and intrarenal angiotensin infusion. Am J Physiol 220: 1309, 1971

27. von Euler US, Floding I: A fluorimetric micromethod for differential estimation of adrenaline and noradrenaline. Acta Physiol Scand 33: (suppl 118) 45, 1955

28. Mayes D, Furuyama S, Kem DC, Nugent CA: A radioimmunoassay for plasma aldosterone. $\mathrm{J}$ Clin Endocrinol 30: 683, 1970

29. Fishman LM, Kuchel O, Liddle GW, Michelakis AM, Gordon RD, Chick WT: Incidence of primary aldosteronism in uncomplicated "essential hypertension". J Am med Ass 205 : 497,1968

30. Luetscher JA, Weinberger MH, Dowdy AJ, Nokes GW, Balikian H, Brodie A, Willoughby S: Effects of sodium loading, sodium depletion and posture on plasma aldosterone concentration and renin activity in hypertensive patients. J Clin Endocrinol Metabol 29: 1310, 1969

31. Crane MG, Harris JJ, Johns VJ, Jr: Hyporeninemic hypertension. Am J Med 52: 457, 1972

32. Spark RF, Melby JC: Hypertension and low plasma renin activity. Presumative evidence for mineral corticoid excess. Ann intern Med 75: 831, 1971

33. Kaplan NM, Silah JG: A new approach to differential diagnosis of renovascular hypertension. New Engl J Med 271: 536, 1964

34. Brenckeridge A: Angiotensin-infusion-test. Lancet II: 209, 1965

35. Higashi $\mathrm{Y}$, Kawasaki T, Tanaka K, Omae T, Katsuki S: A study of angiotensin infusion test with particular reference to the effects of sodium deprivation and potassium loading on pressor dose of angiotensin. Jap J Nephrol 10: 477, 1968 (in Japanese)

36. Weidman P, Endres P, Siegenthaler W: Plasma renin activity and angiotensin pressor dose in hypertension. Correlation and diagnostic implication. Brit Med J III: 154, 1968

37. Distler A, Barth C, Liebau H, Vecsei P, Wolf HP: The effect of tyramine, noradrenaline, and angiotensin on the blood pressure in hypertensive patients with aldosteronism and low plasma renin. Europ J Clin Invest $1: 196,1970$

38. Doyles AE, Frasex FRE, Marschal RJ: Reactivity of forearm vessels to vasoconstrictive substances in hypertensive and nromotensive subjects. Clin Sci 18: 441, 1959

39. Judson WE, Epstein FH, Wilkins RW: The comparative effects of small intravenous dose of l-norepinephrine and epinephrine upon arterial pressure and pulse rate in normotensive subjects and in hypertensive patients before and after thoracolumbar sympathectomy. J Clin Invest 29 : 1414, 1950

40. Gombos EA, Hulet WH, Bopp P, Goldring W, Baldwin DS, Chasis H: Reactivity of renal and systemic circulation to vasoconstrictive substances in normotensive and hypertensive subjects. J Clin Invest 41: 203, 1962

41. Burn $\mathbf{J H}$, Rand $\mathrm{MJ}$ : The action of sympathomimetic amines in animals treated with rcscrpine. J Physiol (London) 144: 314, 1958

42. Mendlowitz M, Naftchi N, Wolf RL, Gitlow SE: The effects of guanethidine and alphamethyldopa on the digital circulation in hypertension. Am Heart J 69: 731, 1965

43. Khairallah RA, Davila D, Papanicolaou N, Glende NH, Meyer P: Effects of angiotensin infusion on catecholamine uptake and reactivity in blood vessels. Circulat Res 28-29 (suppl 
II): 96,1971

44. Peach MJ: Adrenal medullary stimulation induced by angiotensin I, and angiotensin II and analogues. Circulat Res 28-29 (suppl II): 107, 197 I

45. Sato $R$, Masuyama $Y$ : Interaction of angiotensin and noradrenaline in rat's hindlimb preparation. Jap Circulat J 35: 505, 1971

46. Biron $P$, Koiw E, Nowaczynski W, Brouillet $J$, Genest $J$ : The effects of intravenous infusion of valine-5-angiotensin II and other pressor agents on urinary electrolytes and corticoids, including aldosterone. J Clin Invest 40:338, 1961

47. Ito $\mathrm{T}$, Hidaka $\mathrm{H}, \mathrm{Kato} \mathrm{T}$, Yoshitoshi $\mathrm{Y}$ : Response of plasma aldosterone to postural change, diuretica, angiotensin II, sodium restriction or loading and prostaglandin. Jap Heart J 14: 518,1973

48. Vander AJ, Geelhoed G: Inhibition of renin secretion by angiotensin II. Proc Soc Exp Biol Med 120: 399, 1965

49. De Champlain J, Genest J, Veyrat R, Boucher R: Factors controlling renin in man. Arch intern Med 117: 3355, 1966

50. Brunner HR, Baer L, Sealy, JE, Leidingham JGG, Larah JH: The influence of potassium administration and potassium deprivation on plasma renin in normal and hypertensive subjects. J Clin Invest 49:2128, 1970

51. Blair-West JR, Cain JP, Coghlan JP, Denton DA, Funder JW, Scoggins BA, Wright RD: Aldosterone regulation and biojynthesis. Proc Intern Congr Endocrinol, 3rd, Amsterdam: Excepta Med Intern Congr Ser 185: 276, 1969

52. Blair-Weat JR, Coghlan JP, Denton DA, Goldring JR, Murno JA, Peterson RE, Wintour M: Humoral stimulation of adrenal cortical secretion. J Clin Invest 41: 1606, 1962

53. Blair-West JR, Coghlan JP, Denton DA, Goldring JR, Wintour M, Wright RD: The direct effect of increased sodium concentration in sodium deficient sheep. Australian J Exptl Biol Med Sci 44: 455, 1966

54. Gragnon WF, Biglieri EG, Murlow PJ: Mechanisms regulating adrenocortical secretion of aldosterone and glucocorticoids. Recent Progr Hormone Res 22: 381, 1966

55. Bunang RD, Page IH, McCubbin JW: Ncural stimulation of renin release. Circulat Res 19: 851, 1966

56. Vandongen R, Peart WS, Boyd GW: Adrenergic stimulation of renin secretion in the isolated perfused rat kidney. Circulat Res 32: 290, 1973

57. Ueda $H$, Yasuda $H$, Takabatake $Y$, Iizuka $M$, Ihori $M$, Sakamoto $Y$ : Observations on the mechanism of renin release by catecholamines. Circulat Res 26-27 (suppl): 195, 1970.

58. Johnson RL, Davis JO, Witty RT: Effects of catecholamines and renal nerve stimulation on renin release in the nonfiltering kidney. Circulat $R$ es 29:646, 1972

59. Assaykeen TA, Glayton PL, Goldfien A, Gangnon WF: Effect of alpha- and beta-adrenergic blocking agents on the renin response to hypoglycemia and epinephrine in dogs. Endocrino$\log$ 87: 1318, 1970

60. Tanigawa H, Allison DJ, Assaykeen TA: Comparison of the effects of various catecholamines on plasma renin activity alone and in the presence of adrenergic blocking agents. In Hypertension 1972, ed by J Genest, E Koiw, Berlin, Springer-Verlag, p 37, 1972

61. Gagnon WF: Effects of sympathetic activity and ACTH on renin and aldosterone secretion. In Hypertension 1972, ed by J Genest, E Koiw, Berlin, Springer-Verlag, p 4, 1972

62. Gordon RD, Kuchel O, Liddle GW, Island DP: Role of sympathetic nervous system in regulating renin and aldosterone production in man. J Clin Invest 46: 599, 1967

63. Boyd GW, Adamson AR, Arnold M, James VHT, Peart WS: The role of angiotensin II in the control of aldosterone in man. Clin Sci 42: 91, 1972 